\title{
DEFINITION OF THE CURRENT SPREADING PROCESS WAYS IN THE INTERNAL VOLUME OF ORE-THERMAL FURNACE
}

MISHCHENKO V.YU. Assistant Lecturer of the Department of Power Supply of Industrial Enterprises of the Zaporizhzhia National Technical University, Zaporizhzhia, Ukraine, e-mail: m.vlad.u@i.ua;

KACHAN YU.H.

Sci.D, Professor, Professor of the Department of Power Supply of Industrial Enterprises of the Zaporizhzhia National Technical University, Zaporizhzhia, Ukraine, e-mail: yu.kachan@ukr.net;

Purpose. The purpose of this work is the theoretical determination of current spreading ways in the internal volume of the ore-thermal furnace bath. Using the obtained results, it is possible to determine where and in what electrical energy amount is allocated in the working space. It will allow to calculate the bath temperature field.

Methodology. In the course of research work the theory of electrical circuits was used to describe electrical processes and the method of cylindrical coordinates to represent the working space of a bath as a set of mono-volume components.

Findings. The proposed chain of steps to determine the current spreading ways and the calculation formulas to find out the electrical energy input amount to each allocated elemental component of the ore-thermal furnace volume are used. The mathematical formulae to construct the current trajectory flow are proposed.

Originality. For the first time, it was assumed that the trajectory of current flow in the furnace working space has the shape of an arc. It passes between two electrodes and exists both in the horizontal and in the vertical flats of the bath due to the electrical conductivity of the charge materials. The latter, in turn, varies depending on the temperature value. This fact is taken into account when calculating the amount of energy input because of electric current.

Practical value. Subsequently, the implementation of the proposed method for determination the paths of current spreading on a mathematical or physical model allows to obtain data on the amount of electrical energy input at any point in the furnace. Since the process of energy input is one of the first steps in the process of obtaining ferroalloys, the proposed above will allow to calculate various parameters as for one elemental volume (point) and as for the whole furnace bath volume.

Keywords: ore-thermal furnace; elemental volume; current spreading paths; electrical energy.

\section{INTRODUTION}

Modern electric arc and ore-thermal furnaces are quite complex installations with a variety of electromechanical equipment. They consist of a power supply (furnace transformer), a kiln (baths with electrodes) and a short network connecting them together.

Ore-thermal furnaces (OTF) are direct-heating furnaces used to produce ferroalloys, carbides, silicon, phosphorus and other products. The technological processes occurring in its bath are very diverse. Some of them proceed continuously, while others require full melting of loaded materials. The most important parameter of the OTF (ore-thermal furnace) is the electrical resistance of the bath, which depends on a significant number of factors: the strength of materials loaded in the bath, the geometric sizes of the bath, as well as the number and size of the electrodes.

Thermal energy, spent on phase transitions and recovery processes, is released when the electric current passes through the conductive environment. The transformation of electrical energy into heat energy occurs in zones with different aggregate states of materials. In the furnace there is a mixed mode of transformation of elec- tric energy into a heat one.

\section{ANALYSIS OF LAST RESEARCHES}

Modern electric arc and ore-thermal furnaces are complex installations with variety of electromechanical equipment. They consist of a power supply (furnace transformer), a kiln (baths with electrodes) and a short electrical network connecting them together. Traditionally, the furnace working space is divided into three main zones, which are characterized by the nature of energy processes in them [1]. This is an area of materials with relatively low electrical conductivity, an arc zone, and a zone where solid and liquid materials with high electrical conductivity are located. The energy distribution between these zones characterizes the specificy of a concrete process and a concrete furnace.

The spreading of electric current in an ore-thermal bath has been the subject of study for many years. Many theoretical and experimental studies are devoted to this issue. M.S. Maksimenko, F.Ya. Tsybakin, D.A. Diomidovsky, R.A. Sysoyan, P.V. Sergiev and R F. Platonov [2]-[3] studied the current distribution in a single-phase and a three-phase baths on electrolytic models. V.T. Zherdiv gives great importance to the study of the current 
distribution directly in the operating furnaces [4]-[6]. A mathematical simulation of electric fields of three-phase ore-thermal furnaces was also carried out [7].

The studies conducted for ore-thermal furnaces of average power $(7.5 \mathrm{MB} \cdot \mathrm{A})$ for the phosphorus and calcium carbide production allowed to obtain fields for the distribution of the volumetric energy density and the intensity of the electric field in the space between the electrode and the bottom of the furnace [8]. Also, the obtained data on the volumetric energy density distribution and electric field strength allowed to determine the length of the arc and the voltage drop on the arc in furnaces for the phosphorus and calcium carbide production [9]-[10].

The scientist conducted mathematical modeling of electric fields of three-phase ore-thermal furnaces, and also developed the method for conducting theoretical studies with the help of conformal mappings for the determination of physical fields in an ore-thermal melting furnace [11]. Qualitatively, the electric field of the furnace is sufficiently illuminated, but the available information is not enough to calculate accurately the power, electrical transformations and temperatures at each point of the bath volume.

In contrast to the steelmaking furnaces, the current of the electrode in the OTF passes not only through the arc, but also through the charge, where the density and electrical resistance vary as a result of heating [12]. This is the reason of the complexity of obtaining data on arc parameters. In this paper, the method for determining the electric current distribution in the working space of the furnace is proposed by means of simulating the ways of its spreading.

Also, there is a need for further study of the interactions between the parameters of power supply systems and physico-chemical processes occurring in the furnace under various external influences, in order to increase the efficiency of energy and heat and mass exchange processes [13]

\section{FORMULATION OF THE WORK PURPOSE}

The purpose of this work is the theoretical determination of current spreading ways in the internal volume of the ore-thermal furnace bath. With the help of the obtained results it will be possible to determine:

- where in the furnace volume is an electric current;

- in what amount the electrical energy is released in the working space of the furnace due to the electrical resistance of the charge materials.

In the future, the application of the obtained results will allow to calculate the temperature field of the bath

\section{PRESENTATION OF BASIC MATERIAL AND ANALYSIS OF RECEIVED RESULTS}

As indicated in [14], to determine the amount of electrical energy input into each elemental volume of the furnace, it is necessary to establish how exactly the current spreads in the working space of the bath. The charge for smelting ferroalloys is an environment where currents flow through certain trajectories between the electrodes. Let's assume they will have an arc shape and will be directed to the edges of the bath and to its center in the horizontal plane. In the vertical plane, they will pass between the ends of the electrodes towards the bottom of the bath. This assumption is made on the basis of scientific papers [9]-[10] in which trajectories of currents flow in the sub-electrode space are depicted as lines directed from the electrode to the bottom of the bath of the OTF and have an arc type.

Simulating melting area occurs in $H_{c \text { - }}$ parameter - the depth of bath charge filling. The zero point is the upper limit of its filling. The paths of current flow between the electrodes in the horizontal plane can be represented as arcs with radii passing through the centers of the electrodes and shifted in the direction towards the edges of the bath $R_{a+}$ and to its center $R_{a-}$.

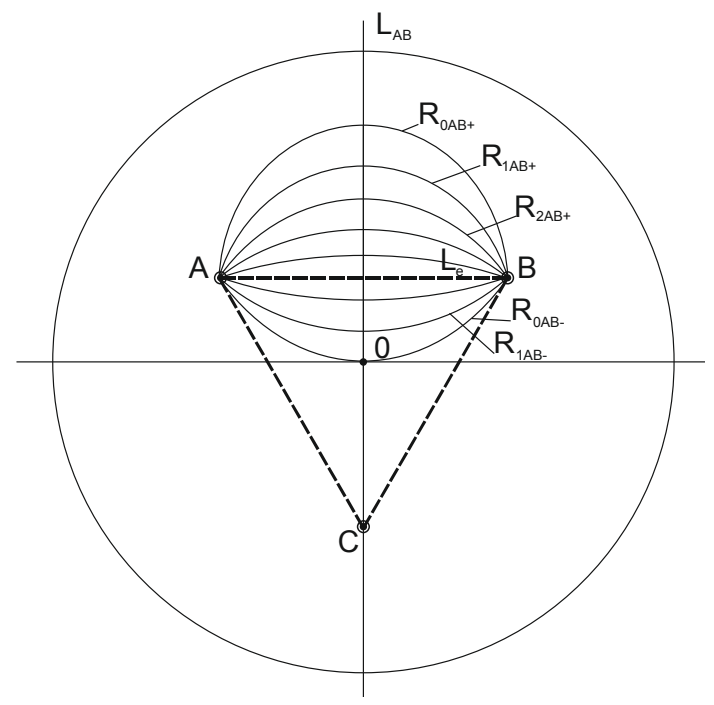

Figure 1. Ways of current spreading between the electrodes of $A$ and $B$ phases.

In order to hold the arcs between the electrodes, it is necessary to know its radius and coordinates of the centers. The latter are on a line passing through the third electrode perpendicular to the shortest path between the two other ones. The radius and the length of each arc can be calculated using formulae. The latter were received and somewhat modified by the well-known geometric dependencies for finding different circle parameters.

We modulate the paths of current flow between the electrodes of $A$ and $B$ phases in the direction towards the edges of the furnace bath. Between the centers of the electrodes, a length $L_{e}$ line is made. Calculate the radius changing step of the arc:

$$
\Delta k_{a . c+}=\frac{L_{e}}{2 \cdot k_{a . c+}},
$$

where $L_{e}$ is the distance between the centers of the electrodes; $k_{a c_{+}+}$is the number of the accepted current spreading paths between the $A$ and $B$ electrodes in the direction 
towards the edges of the furnace bath.

Now we draw a zero arc with $R_{a 0 A B}+$ and with the center located in the middle of the indicated $L_{e}$ line. Its radius and length are determined by the formulae (2)-(3).

$$
\begin{gathered}
R_{a 0 A B+}=\frac{L_{e}}{2} \\
L_{a 0 A B+}=2 \cdot \arcsin \left(\frac{L_{e}}{2 \cdot R_{a 0 A B+}}\right) \cdot R_{a 0 A B+}
\end{gathered}
$$

In order to draw the next arc, we calculate its radius and shift of the center point to the distance from the $L_{e}$ line toward the center of the furnace along the $L_{A B}$ line passing between the centers of the furnace bath and the third electrode in the $C$ phase using the formulae (4)-(5):

$$
\begin{gathered}
R_{a 1}=\frac{\left(L_{e} / 2-\Delta k_{a . c} \cdot 1\right)}{2}+\frac{L_{e}{ }^{2}}{8 \cdot\left(L_{e} / 2-\Delta k_{a . c} \cdot 1\right)} \\
-c \cdot p \cdot R_{a 1}=\sqrt{R_{a 1}^{2}-\left(L_{e} / 2\right)^{2}}
\end{gathered}
$$

For any type of an arc, (3)-(5) formulae take the following form (6)-(8):

$$
\begin{gathered}
R_{a i}=\frac{\left(L_{e} / 2-\Delta k_{a, c} \cdot i\right)}{2}+\frac{L_{e}^{2}}{8 \cdot\left(L_{e} / 2-\Delta k_{a, c} \cdot i\right)} \\
-c \cdot p \cdot R_{a i}=\sqrt{R_{a i}^{2}-\left(L_{e} / 2\right)^{2}} \\
L_{a i}=2 \cdot \arcsin \left(\frac{L_{e}}{2 \cdot R_{a i}}\right) \cdot R_{a i}
\end{gathered}
$$

where $i$ is an arc number, which varies from 0 to $k_{\text {a.c. }}$

To simulate current spreading paths between the electrodes of $A$ and $B$ phases in the direction to the center of the furnace bath, the following calculations are required. As noted above, all points of the arc centers are on the $L_{A B}$ line, and the zero reference point is its intersection with the $L_{e}$ line. In this case we adjust the zero reference point by moving it to distance $+c . p . R_{a 0}$ and calculating the radius of the zero arc $R_{a 0 A B-}$, with the radius changing step $\Delta k_{a . c}$ :

$$
\begin{gathered}
R_{a 0 A B-}=R_{e} \\
+c . p \cdot R_{a 0}=\frac{R_{e}}{2} \\
\Delta k_{a . c-}=\frac{R_{e}}{2 \cdot k_{a . c-}}
\end{gathered}
$$

where $k_{a . c_{-}}-$is the number of ways of distributing current between $A$ and $B$ electrodes in the direction towards the center of the furnace bath; $R_{e}$ is the radius on which the electrodes are located relatively to the center of the furnace bath.

To draw the following arcs, we will use the abovedescribed algorithm and formulae (6)-(8) but with $i$ varying in the range from 0 to $k_{\text {a.c. }}$. As a result, we obtain a picture of current spreading between the electrodes shown in Fig. 1. Similarly, the process of the current spreading paths simulating between the $B C$ and $C A$ phases.

The ore-thermal furnace bath has a volume; thus, by analogy with the step $\Delta z$ along the $H_{c}$ axis, we repeat the process of current spreading paths simulating to the depth of the electrodes immersion in the charge. Since the current flows in the sub-electrode space of the bath, it should be also considered. To do this, it's necessary to change the direction of the straight line on which the arc centers are located, under the selected angles relative to the horizontal-vertical component of the furnace bath.

To simulate the process of distributing energy in an ore-thermal furnace bath, first of all, it is necessary to break its internal area into elemental volumes. There are a lot of methods for this; we have chosen and somewhat changed the method based on the system of cylindrical coordinates, which was used earlier to construct a dynamic temperature field model in an electric heat accumulating converter [15].

The geometric bath of an ore-thermal furnace, where the melting process takes place, can be represented as a cylinder of height $H$ and radius $R$. We break it into a series of elemental volumes in the form of a sector with the sides $\Delta R, \Delta z$ and the angle $\Delta \varphi$, as represented on Fig. 2. We will place further calculation points in the geometric centers of the elemental sectors selected in this way.

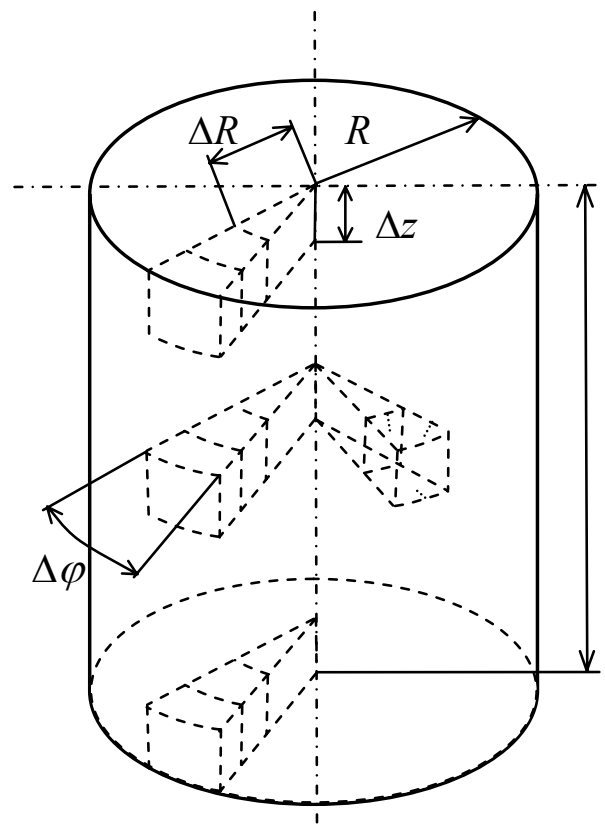

Figure 2. Breakdown of the OTF bath on elemental volumes.

Let's introduce the following notation: $R l$-radius of the bath; $\Delta V$ - the volume of the elemental sector; $k-$ number of elemental volume behind the axis $R ; N \varphi$ is the number of segments $\Delta \varphi$ of the broken cylinder's volume in an angle $\varphi ; N z$ - the number of intervals $\Delta z$ of the broken cylinder's volume at the height $H c$ filling the bath 
with the charge; $R, \varphi, z$ are the coordinates of the center; $\Delta \tau$ is the time interval.

The specified parameters $\Delta z$ and $\Delta \varphi$ are calculated as follows:

$$
\begin{array}{r}
\Delta \varphi=\frac{360}{N_{\varphi}} . \\
\Delta z=\frac{H_{c}}{N_{z}} .
\end{array}
$$

Assuming the constant value $\Delta V$ for each elemental volume, we define the intervals $\Delta R k$ for the $R$ axis:

$$
\Delta R_{k}=\sqrt{\frac{\Delta V \cdot N_{\varphi}}{\pi \cdot \Delta z}} \cdot(\sqrt{k+1}-\sqrt{k}) .
$$

After determining all the necessary parameters for this break, it becomes possible to represent the OTF bath as a set of single-volume elements. Due to arbitrary values of $\Delta V, N \varphi$ and $N z$, you can change the total number of elemental volumes, thus providing the necessary prediction error when performing various mathematical calculations.

So, if you make a very fractional volume break, the speed of the necessary calculations is slowed down through a large array of data. When the working space of the furnace is divided into a small number of elemental volumes, this can lead to inadequacy of the resulting model.

After the current spreading paths have been determined, using the proposed version of the partition of the OTF working space on the elemental volumes, we obtain a two-dimensional image presented in Fig. 3 in the horizontal plane and in the sub-electrode space as in Fig. 4.

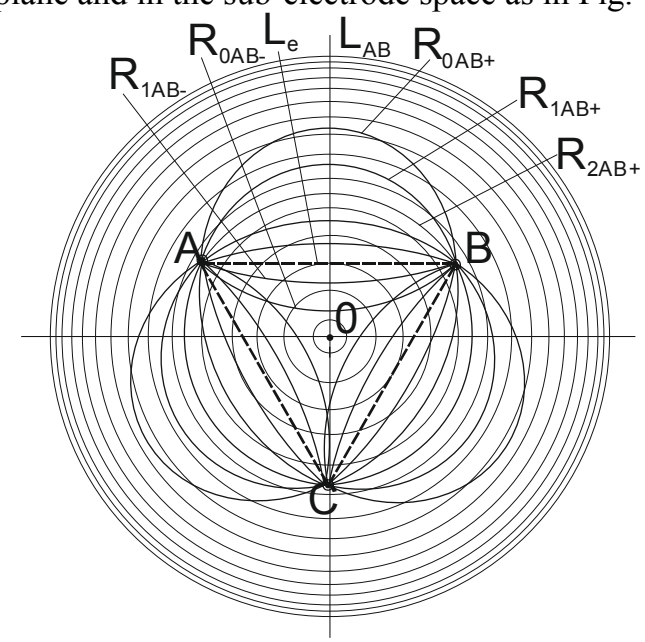

Figure 3. The current spreading paths between the three electrodes in the working space of the bath, the volume of which is pre-divided into elementary components

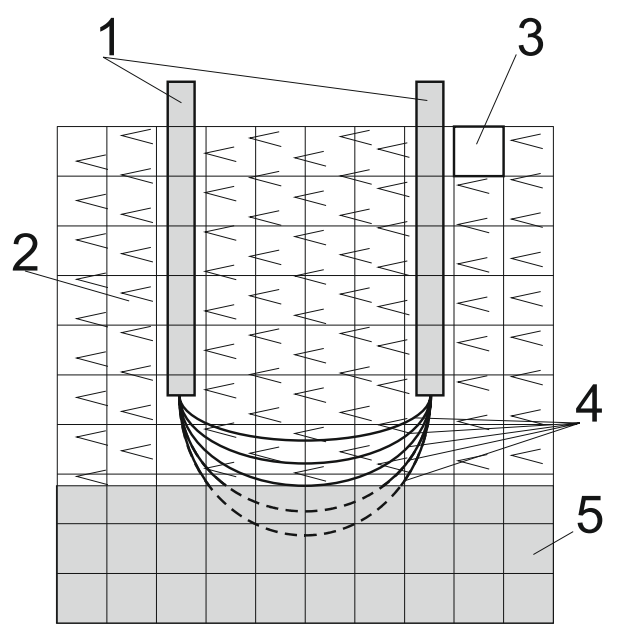

1 - electrodes; 2 - charge in solid state; 3 -elementary volume; 4 ways of current spreading; 5 - liquid melt.

Figure 4. Ways of current spreading between the electrodes in the sub-electrode space

The charge in each single volume of elemental component $\Delta V$ at a certain temperature has its specific electrical resistance [16]. The average electrical resistance can be calculated as:

$$
X_{R, \varphi, z}=\rho_{R, \varphi, z}(t) \cdot \Delta V,
$$

where $X_{R, \varphi, z}$ - the average value of the electrical resistance of the element; $\Delta V$ - the volume of the elementary part; $\rho_{R, \varphi, z}(t)$ - the specific resistance of elemental volume.

Using ways of current spreading in the OTF working space and breaking the bath into elemental volumes on the base of the proposed method, it is possible to calculate the amount of electrical energy introduced into them for a certain period of time. To do this, it is necessary to allocate a specific trajectory of current flow and calculate its full electrical resistance. The latter can be defined as the total resistance of all charge sections through which the described current passes:

$$
X_{t}=\sum X_{R, \varphi, z} .
$$

where $X_{t}$ - full electrical resistance of any trajectory of current flow; $X_{R, \varphi, z}$ - the average value of the electrical resistance of the element.

Obviously, in the given coordinate system, it is necessary to select only those elementary volumes where the current passed and the resulting resistance is summed up, which is calculated for a specific temperature of the charge. As a result, the value of the current spreading over the observed lines can be obtained:

$$
I_{i}=\frac{U}{X_{t}},
$$

where $I_{i}$ - current strength on the i-th way; $U$ - voltage between the corresponding phases; $X_{t}$ - full electrical resistance on the i-th path. 
Consequently, substituting the expressions $(16,15)$ in formula (17), we obtain the dependence for defining the current strength along certain spreading trajectory:

$$
I_{i}=\frac{U}{\sum \rho_{R, \varphi, z}(t) \cdot \Delta V},
$$

where $I_{i}$ - current strength on the i-th way; $U$ - voltage between the corresponding phases; $\rho_{R, \varphi, z}(t)$ - specific resistance of elemental volume; $\Delta V$ - volume of elementary particle.

As a result, the amount of energy emitted in the elemental volume due to electric current over a time interval $\Delta \tau$ can be defined as:

$$
Q_{e(R, \varphi, z)}=I_{i}^{2} \cdot X_{R, \phi, z} \cdot \Delta \tau,
$$

where $I_{i}$ - current strength on the i-th way; $X_{R, \varphi, z}$ - the average value of the electrical resistance of the element; $\Delta \tau$ - time interval.

If, however, through one and the same elemental volume passes several different trajectories of current spreading, then the resulting value of the latter is determined as the sum of the components for each of them. Then the formula (18) will take the following form:

$$
Q_{e(R, \varphi, z)}=\left(\sum I_{i}\right)^{2} \cdot R_{R, \phi, z} \cdot \Delta \tau,
$$

where $\Sigma I_{i}$ is the sum of currents along the same spreading paths passing through the elemental volume under consideration.

The presented trajectories of current flow are conditional. That is, in some paths current may not pass at all or its value will be negligible. It depends on the electrical resistance of the charge section.

Determining the flow of current in the furnace bath is one of the components in the development of a comprehensive mathematical model of the work of the OTF in dynamics, which is the main purpose of the authors of the article. Therefore, the reliability of the proposed method will be possible to verify only after the implementation of the entire complex model on electronic computing. The given model of the current distribution in the furnace can be used in the simulation of electrical processes in all orethermal furnaces, regardless of what grade of ferroalloys in them is smelted.

As to the limitations for use, this technique can not be used for steelmaking furnaces, since technologically, electrodes in them are placed above the surface of the melt and the current flows in the air layer as a result of the closure between the electrode and the charge. That is, in such furnaces, the latter is not conductive medium, but only its surface, so to speak, is zero in an electric circle to form a powerful energy arc. The presented model is based on the fact that the current flows in the horizontal and vertical planes between the electrodes due to the electric resistance of the charge.
As a result, with the help of the given algorithm for determining the current spreading paths, the methods of partitioning the internal working space of the OTF into the elemental volumes and the formulae used, we can watch electric energy distribution in the furnace bath in the three-dimensional space.

\section{V.CONCLUSION}

The process of electrical current spreading simulation in the bath of an ore-thermal furnace is described in this paper mathematically. It is suggested to assume that trajectories of current passing through the charge have the form of arcs which are located between the centers of the electrodes and move in the direction towards the edges of the bath and to its center. On the basis of the presented model, it is possible to determine the volumes of the introduced electricity and their distribution in the bath volume.

As it can be seen on Figure 3, due to the distance between the electrodes, the zones of the electric current flow inaccessibility appear. Therefore, there is such an optimal distance between them, when it is possible to cover the entire furnace bath working area in horizontal plane with the help of current spreading paths. Otherwise, in the orethermal furnace space, the charge heating occurs only at the expense of heat transfer, and this is a long-time process.

This method of the OTF bath calculating with the help of elemental volumes based on the system of cylindrical coordinates is proposed here. Representation of the working space of the bath as a set of single- volume elements makes it possible to perform various mathematical calculations in the geometric centers of these elements. And this, in turn, will allow us to obtain a more precise picture of all physical processes occurring during the smelting of ferroalloys at different points of the OTF bath at any time.

\section{REFERENCE}

[1] Nehamin, S.M. (2013). Upravleniye energeticheskoy strukturoy rabochego prostranstva dugovykh staleplavil'nykh i rudnotermicheskikh pechey mekhanizm povysheniya effektivnosti ikh raboty. Elektrometallurgija. 11, 9-16.

[2] Sergeev, P.V. (1963). Energeticheskiye zakonomernosti rudnotermicheskikh elektropechey, elektroliza i elektricheskoy dugi Moscow, Metallurgy, 368.

[3] Platonov, G.F. (1965). Parametry i elektricheskiye rezhimy metal-lurgicheskikh elektrodnykh pechey. Moscow, Energija, 224.

[4] Strunskij, B.M. (1972). Rudnotermicheskiye plavil'nyye pechi. Moscow, Metallurgija, 368.

[5] Sisojan, G.A. (1961). Elektricheskaya duga v elektricheskoy pechi. Moscow, Metallurgizdat, 216.

[6] Al'tgauzen A.P. (1967 Elektrotermicheskoe oborudovanie. Spravochnik, Moscow, Jenergija, 216.

[7] Oldziyevsky, S.A., Kravchenko, A.V., Nzhurin, V.I., Borisenko, I.A. (1990). Matematicheskoye modeliro- 
vaniye elektricheskikh poley pechey rudnoy elektrotermii [Tekst]. Moscow, Metallurgy, 114.

[8] Yershov, V.A., Dancyz, Ya.B., Zhilov, G.M. (1974). Teoreticheskie osnovy himicheskoj elektrotermii. Leningrad, Himija, 184.

[9] Danzys, Ya.B., Zhilov, G.M., Valkov, Z.A. (1991). Elektricheskie harakteristiki dugovogo razrjada pechej himicheskoj elektrotermii i sposoby ih kontrolia. Leningrad, LNGK, 54.

[10]Danzys Ya.B., Yershov, V.A., Zhilov, G.M. (1984). Elektrotermicheskie processy himicheskoi tehnologii: Uchebnoe posobie dlia vuzov. Leningrad, Himija, 464.

[11]Levchenko, S.A., (2016). Elektromagnitne ta teplove polia rudnotermichnoi' plavylnoi' pechi. Visnyk NTU «HPI». Serija, Mehaniko-tehnologichni systemy ta kompleksy. 17(1189), 76-80.

[12]Kachan, Yu.G., Mishchenko, V.Yu. (2017). Shchodo zminyuvannya pytomoho elektrychnoho oporu shykhty pid chas vyplavky vysoko vuhletsevoho feromarhantsyu. Metalurgija : naukovi pratsi Zaporizkoyi derzhavnoyi inzhenernoyi akademiyi, Zaporizhzhia, RVV ZDIA, 2 (38), 131-133.
[13]Artjuh. F.S., Kuharev. A.L. (2014). Puti povyshenija energojeffektivno-sti moshhnyh elektropechnyh ustanovok. Visnik NTU «HPI». Serija, Energetika: nadijnist' ta energoefektivnist', Harkiv: NTU «HPI», 56 (1098), 11-21.

[14]Kachan, Yu.G., Mishchenko, V.Yu. (2018). Shhodo kompleksnogo pidhodu pry modeljuvanni roboty rudnotermichnoi' pechi. Metalurgija : naukovi praci Zaporiz'koi' derzhavnoi' inzhenernoi' akademii'. Zaporizhzhja, RVV ZDIA No 1 (39), 94-96.

[15]Kachan, Yu.G., Batasova, N.A. (2007). Dinamicheskaja model' temperaturnogo polja $\mathrm{V}$ elektricheskom teploakkumulirujushhem preobrazovatele. Teorija i praktika metallurgii. Dnepropetrovsk, 6 (61), 63-66.

[16]Bakyrov, A.H., Zhunusov, A.K., Chekymbaiev, A.F. and Shoshai, Zh., (2018). Issledovanie udel'nogo elektricheskogo soprotivlenija shihtovyh smesej dlia vyplavki ferrosilikoaljuminiia Nauka i tehnika Kazahstana. Pavlodar, 2, 14-18.

\section{ВИЗНАЧЕННЯ ШЛЯХІВ РОЗТІКАННЯ СТРУМУ У ВНУТРІШНЬОМУ ОБ'СМІ РУДНОТЕРМІЧНОЇ ПЕЧІ}

МІЩЕНКО В.Ю. асистент кафедри електропостачання промислових підприємств Запорізького начіонального технічного університету, Запоріжжя, Україна, е-таіl: m.vlad.u@i.ua;

КАЧАН Ю.Г. підприсмств Запорізького наиіонального технічного університету, Запоріжжя, Україна, e-mail: yu.kachan@ukr.net;

Мета роботи. Метою даної роботи є теоретичне визначення траєкторій розтікання струму у внутрішньому об'ємі ванни руднотермічної печі. За допомогою отриманих результатів стане можливим визначити де та в якій кількості виділяється електрична енергія в робочому просторі. Це, в подальшому, дозволить проводити розрахунок температурного поля ванни.

Методи дослідження. При проведення досліджень було використано теорію електричного кола для опису електричних процесів та метод ичиліндричних координат для представлення робочого простору ванни як сукупність однооб' 'ємних складових.

Отримані результати. Запропонована послідовність для визначення шляхів розтікання струму та розрахункові формули для визначення кількості введеної електричної енергії у кожну виділену елементарну складову об'єму руднотермічної печі. Представлені математичні формули для побудови траєкторії протікання струму.

Наукова новизна. Вперше зроблене припущення, що траєкторія протікання струму у робочому просторі печі має форму дуги. Вона проходить між двома електродами й існує як в горизонтальній, так і у вертикальній площинах ванни за рахунок електропровідності шихтових матеріалів. Останне, в свою чергу, змінюється в залежності від значення температури. Цей факт враховано при розрахунках кількості введеної енергії за рахунок електричного струму.

Практична чінність. В подальшому реалізація запропонованого методу для визначення шляхів розтікання струму на математичній чи фізичній моделі дозволить отримати дані про кількість введеної електричноі енергії в будь-якій точиі печі. Так як прочес введення енергії є одним із перших кроків в технологічному процесі одержсання феросплавів, то запропоноване вище, в свою чергу, дасть змогу проводити подальші розрахунки різних параметрів як одного елементарного об'єму (точки), так $і$ ванни печі в цілому.

Ключові слова: руднотермічна піч; елементарний об'єм; иляхи розтікання струму; електрична енергія. 


\title{
ОПРЕДЕЛЕНИЕ ПУТЕЙ РАСТЕКАНИЯ ТОКА ВО ВНУТРЕННЕМ ОБЪЕМЕ РУДНОТЕРМИЧЕСКОЙ ПЕЧИ
}

\author{
МИЩЕНКО В.Ю. ассистент кафедры электроснабжения промышленных предприятий \\ Запорожского начионального технического университета, Запорожье, Украина, е- \\ mail:m.vlad.u@i.ua; \\ КАЧАН Ю.Г. д-р техн. наук, профессор, профессор кафедры электроснабжения промышленных \\ предприятий Запорожского национального технического университета, \\ 3апорожье, Украина, e-mail: yu.kachan@ukr.net;
}

Цель работы. Целью данной работы является теоретическое определение путей растекания тока во внутреннем объеме ванны руднотермической печи. С помощью полученных результатов станет возможным определять где и в каком количестве выделяется электрическая энергия в рабочем пространстве. Это, в дальнейшем, позволит проводить расчет температурного поля ванны.

Методы исследования. При проведении исследований была использована теория электрических иепей для описания электрических прочессов и метод иилиндрических координат для представления рабочего пространства ванны как совокупность однообъемных составляющих.

Полученные результаты. Предложена последовательность для определения путей растекания тока и расчетные формуль для определения количества введенной электрической энергии в каждую выделенную элементарную составляюшую объема руднотермической печи. Представлены математические формулы для построения траектории протекания тока.

Научна новизна. Впервые сделано предположение, что траектория протекания тока в рабочем пространстве печи имеет форму дуги. Она проходит между двумя электродами и существует как в горизонтальной, так и в вертикальной плоскостях ванны за счет электропроводности шихтовых материалов. Последнее, в свою очередь, меняется в зависимости от температуры. Этот факт учтен при расчетах количества введенной энергии за счет электрического тока.

Практическая ченность. В дальнейшем реализаиия предложенного метода для определения путей растекания тока на математической или физической модели позволит получить данные о количестве введенной электрической энергии в любой точке печи. Так как процесс введения энергии является одним из первых шагов в технологическом прочессе получения ферросплавов, то предложенное выше, в свою очередь, позволит проводить дальнейшие расчеты различных параметров как для одного элементарного объема (точки), так и для ванны печи в целом.

Ключевые слова: руднотермическая печь; элементарный объем; пути растекания тока; электрическая энергия. 